\title{
Front Matter: Volume 6929
}

"Front Matter: Volume 6929," Proc. SPIE 6929, Behavior and Mechanics of Multifunctional and Composite Materials 2008, 692901 (12 May 2008); doi: 10.1117/12.800810

SPIE Event: SPIE Smart Structures and Materials + Nondestructive Evaluation and Health Monitoring, 2008, San Diego, California, United States 


\title{
PROCEEDINGS OF SPIE
}

\section{Behavior and Mechanics of Multifunctional and Composite Materials 2008}

\author{
Marcelo J. Dapino \\ Zoubeida Ounaies \\ Editors \\ 10-13 March 2008 \\ San Diego, California, USA \\ Sponsored by \\ SPIE \\ Cosponsored by \\ American Society of Mechanical Engineers (USA) \\ Cooperating Organizations \\ Intelligent Materials Forum (Japan) \\ Jet Propulsion Laboratory (USA) \\ National Science Foundation (USA) \\ Published by \\ SPIE
}

Volume 6929 
The papers included in this volume were part of the technical conference cited on the cover and title page. Papers were selected and subject to review by the editors and conference program committee. Some conference presentations may not be available for publication. The papers published in these proceedings reflect the work and thoughts of the authors and are published herein as submitted. The publisher is not responsible for the validity of the information or for any outcomes resulting from reliance thereon.

Please use the following format to cite material from this book:

Author(s), "Title of Paper," in Behavior and Mechanics of Multifunctional and Composite Materials 2008, edited by Marcelo J. Dapino, Zoubeida Ounaies, Proceedings of SPIE Vol. 6929 (SPIE, Bellingham, WA, 2008) Article CID Number.

ISSN 0277-786X

ISBN 9780819471154

Published by

SPIE

P.O. Box 10, Bellingham, Washington $98227-0010$ USA

Telephone +1 3606763290 (Pacific Time) · Fax +1 3606471445

SPIE.org

Copyright (c) 2008, Society of Photo-Optical Instrumentation Engineers

Copying of material in this book for internal or personal use, or for the internal or personal use of specific clients, beyond the fair use provisions granted by the U.S. Copyright Law is authorized by SPIE subject to payment of copying fees. The Transactional Reporting Service base fee for this volume is $\$ 18.00$ per article (or portion thereof), which should be paid directly to the Copyright Clearance Center (CCC), 222 Rosewood Drive, Danvers, MA 01923. Payment may also be made electronically through CCC Online at copyright.com. Other copying for republication, resale, advertising or promotion, or any form of systematic or multiple reproduction of any material in this book is prohibited except with permission in writing from the publisher. The CCC fee code is 0277-786X/08/\$18.00.

Printed in the United States of America.

Publication of record for individual papers is online in the SPIE Digital Library.

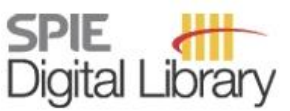

SPIEDigitalLibrary.org

Paper Numbering: Proceedings of SPIE follow an e-First publication model, with papers published first online and then in print and on CD-ROM. Papers are published as they are submitted and meet publication criteria. A unique, consistent, permanent citation identifier (CID) number is assigned to each article at the time of the first publication. Utilization of CIDs allows articles to be fully citable as soon they are published online, and connects the same identifier to all online, print, and electronic versions of the publication. SPIE uses a six-digit CID article numbering system in which:

- The first four digits correspond to the SPIE volume number.

- The last two digits indicate publication order within the volume using a Base 36 numbering system employing both numerals and letters. These two-number sets start with $00,01,02,03,04,05$, 06, 07, 08, 09, OA, OB ... 0Z, followed by 10-1Z, 20-2Z, etc.

The CID number appears on each page of the manuscript. The complete citation is used on the first page, and an abbreviated version on subsequent pages. Numbers in the index correspond to the last two digits of the six-digit CID number. 


\section{Contents}

ix Symposium Committee

xi Conference Committee

\section{SESSION 1 FERROELECTRICS I}

$692903 \quad$ Extended life PZT stack test fixture [6929-02]

M. Badescu, S. Sherrit, X. Bao, J. Aldrich, Y. Bar-Cohen, C. Jones, Jet Propulsion Lab. (USA)

692906 The effect of environmental temperature on the performance of piezoelectric transformer [6929-05]

Y. Y. Chen, K.-T. Chen, National Taiwan Univ. (Taiwan); C. K. Lee, National Taiwan Univ.

(Taiwan) and Industrial Technology Research Institute (Taiwan)

\section{SESSION 2 FERROELECTRIC MATERIALS: CHARACTERIZATION}

692907 Experimental study of the electro-mechanical switching behavior of a piezoelectric stack actuator [6929-07]

A. York, S. Seelecke, North Carolina State Univ. (USA)

692908 Compositional dependence of single-crystal PMN-xPT phase transformations [6929-06] K. G. Webber, Georgia Institute of Technology (USA); C. S. Lynch, Univ. of California, LoS Angeles (USA)

692909 Multilayer piezoelectric stack actuator characterization [6929-08]

S. Sherrit, C. M. Jones, J. B. Aldrich, C. Blodget, X. Bao, M. Badescu, Y. Bar-Cohen, Jet Propulsion Lab. (USA)

6929 OB Inhomogeneous creep fields in PLZT: an experimental study [6929-10]

Q. D. Liu, Univ. of Cambridge (United Kingdom); J. E. Huber, Univ. of Oxford (United Kingdom)

\section{SESSION 3 FERROELECTRIC MATERIALS: MODELING}

6929 OC Reverse polarization switching in ferroelectric lead zirconate titanate (PZT) thin films [6929-11]

W. S. Oates, Florida A\&M Univ. (USA) and Florida State Univ. (USA)

6929 OE A rate-dependent incremental variational formulation of ferroelectricity [6929-13]

D. Rosato, C. Miehe, Univ. Stuttgart (Germany)

6929 OF Micromechanical model of nonlinear relaxor ferroelectric phase transformation [6929-14] K. G. Webber, Georgia Institute of Technology (USA); C. S. Lynch, Univ. of California, Los Angeles (USA) 
692901 Design of a new structural health monitoring based on piezoelectric sensors for detection of strains of various amplitudes [6929-18]

C. Wakabayashi, Tokyo Institute of Technology (Japan); H. Sato, National Institute of Advanced Industrial Science and Technology (Japan); M. Taya, Univ. of Washington (USA)

6929 0J Phase-field modeling of domain switching near crack tips in single crystal ferroelectrics [6929-96]

W. Li, C. M. Landis, The Univ. of Texas at Austin (USA)

\section{SESSION 5 ACTIVE POLYMERS}

$6929 \mathrm{OL}$ Magnetic and electric field alignments of cellulose chains for electro-active paper actuator [6929-21]

S. Yun, Y. Chen, S. W. Lee, J. Kim, Inha Univ. (South Korea); H. S. Kim, Catholic Univ. of Daegu (South Korea)

6929 OM Rotational isomeric state theory applied to the stiffness prediction of an anion polymer electrolyte membrane [6929-22]

F. Gao, Univ. of Pittsburgh (USA) and National Energy Technology Lab. (USA); L. M. Weiland, Univ. of Pittsburgh (USA); J. Kitchin, National Energy Technology Lab. (USA) and Carnegie Mellon Univ. (USA)

6929 ON High surface area electrodes in ionic polymer transducers: numerical and experimental investigations of the chemo-electric behavior [6929-23]

B. J. Akle, Lebanese American Univ. (Lebanon); T. Wallmersperger, Univ. Stuttgart (Germany); E. Akle, American Univ. of Beirut (Lebanon); D. J. Leo, Virginia Polytechnic Institute and State Univ. (USA)

692900 Fabrication and characterization of piezo-paper made with cellulose [6929-24] H. S. Kim, Catholic Univ. of Daegu (South Korea); S. Yun, J.-H. Kim, G. Y. Yun, J. Kim, Inha Univ. (South Korea)

6929 OP Self-healing of bilayer lipid membranes formed over silicon substrates with a single pore [6929-25]

M. A. Creasy, D. Hopkinson, D. J. Leo, Virginia Polytechnic Institute and State Univ. (USA)

\section{SESSION 6 ACTIVE COMPOSITES I}

$69290 Q \quad F a t i g u e$ characteristics of carbon nanotube blocks under compression [6929-86] J. Suhr, Univ. of Nevada, Reno (USA); L. Ci, Rice Univ. (USA); P. Victor, Applied Materials, Inc. (USA); P. M. Ajayan, Rice Univ. (USA)

6929 OS Self-sensing and self-actuating CFRP structure using partially flexible composites [6929-29] K. Kumagai, A. Todoroki, R. Matsuzaki, Tokyo Institute of Technology (Japan) 
6929 OV Integration of sensing networks into laminated composites [6929-31]

F. Ghezzo, P. Rye, Y. Huang, S. Nemat-Nasser, Univ. of California, San Diego (USA)

6929 OW Acoustic performance and compression behaviour of perforated aluminium foam [6929-32]

J. McRae, H. E. Naguib, Univ. of Toronto (Canada); N. Atalla, Univ. de Sherbrooke (Canada)

6929 OX 3D FEA simulation of segmented reinforcement variable stiffness composites [6929-33] C. P. Henry, G. P. McKnight, HRL Labs., LLC (USA); A. Enke, R. Bortolin, S. Joshi, NextGen Aeronautics, Inc. (USA)

6929 OZ Wave dispersion in a cellular composite with modulated microstructure [6929-35] V. Kumar, D. R. Mahapatra, Indian Institute of Science (India)

\section{SESSION 8 FUTURE OF SMA I}

692912 Influence of test procedures on the thermomechanical properties of a 55NiTi shape memory alloy [6929-38]

S. A. Padula II, NASA Glenn Research Ctr. (USA); D. J. Gaydosh, Ohio Aerospace Institute (USA); R. D. Noebe, G. S. Bigelow, NASA Glenn Research Ctr. (USA); A. Garg, Univ. of Toledo (USA); D. Lagoudas, I. Karaman, K. C. Atli, Texas A\&M Univ. (USA)

692913 Experimentally validated numerical analysis of aerostructures incorporating shape memory alloys [6929-39]

D. J. Hartl, J. T. Mooney, D. C. Lagoudas, Texas A\&M Univ. (USA); J. H. Mabe, F. T. Calkins, The Boeing Co. (USA)

692914 Low-cycle superelastic response of a titanium-niobium shape memory alloy [6929-40] J. Ma, I. Karaman, Texas A\&M Univ. (USA); H. J. Maier, Univ. of Paderborn (Germany)

\section{SESSION 9 FUTURE OF SMA II}

692916 Thermomechanical cyclic loading and fatigue life characterization of nickel rich NiTi shape-memory alloy actuators [6929-42]

O. W. Bertacchini, D. C. Lagoudas, Texas A\&M Univ. (USA); F. T. Calkins, Boeing Commercial Airplane Co. (USA); J. H. Mabe, Boeing Phantom Works (USA)

692919 Large strain variable stiffness composites for shear deformations with applications to morphing aircraft skins [6929-45]

G. P. McKnight, C. P. Henry, HRL Labs., LLC (USA)

\section{SESSION 10 SHAPE-MEMORY MATERIALS I}

6929 1B Thermomechanical characterization of the nonlinear rate-dependent response of shape memory polymers [6929-46]

B. L. Volk, D. C. Lagoudas, Texas A\&M Univ. (USA); Y.-C. Chen, Univ. of Houston (USA) 
6929 1C Damping of high-temperature shape memory alloys [6929-48]

K. P. Duffy, Univ. of Toledo (USA) and NASA Glenn Research Ctr. (USA); S. A. Padula II, NASA Glenn Research Ctr. (USA); D. A. Scheiman, ASRC (USA) and NASA Glenn Research Ctr. (USA)

6929 ID Simultaneous transformation and plastic deformation in shape memory alloys [6929-49] D. J. Hartl, D. C. Lagoudas, Texas A\&M Univ. (USA)

6929 IF Shakedown response of conditioned shape memory alloy wire [6929-51]

C. B. Churchill, J. A. Shaw, Univ. of Michigan (USA)

6929 1G Shape memory alloy cables [6929-52]

B. Reedlunn, J. A. Shaw, Univ. of Michigan (USA)

6929 1H Model development for shape memory polymers [6929-53]

R. D. Siskind, R. C. Smith, North Carolina State Univ. (USA)

692911 Development of multifunctional wire that combines shape-memory alloy to piezo electric material [6929-54]

H. Sato, National Institute of Advanced Industrial Science and Technology (Japan)

6929 1J Structural evaluation of a nickel base super alloy metal foam via NDE and finite element [6929-55]

A. Abdul-Aziz, NASA Glenn Research Ctr. (USA); G. Abumeri, M. Garg, AlphaSTAR Corp.

(USA); P. G. Young, Univ. of Exeter (United Kingdom)

$69291 \mathrm{~K}$ Carbon nanotube (CNT) fins for enhanced cooling of shape memory alloy wire [6929-56]

A. Pathak, Univ. of Michigan (USA); J. AuBuchon, Univ. of California, San Diego (USA);

D. Brei, J. Shaw, J. Luntz, Univ. of Michigan (USA); S. Jin, Univ. of California, San Diego (USA)

6929 IL Electro-induced shape-memory polymer nanocomposite containing conductive particles and short fibers [6929-57]

H. Lv, J. Leng, S. Du, Harbin Institute of Technology (China)

\section{SESSION 12 MAGNETIC SHAPE-MEMORY ALLOYS I}

692910 A continuum thermodynamics formulation for micro-magneto-mechanics with applications to ferromagnetic shape memory alloys: application to domain wall-twin boundary dissociation [6929-60]

C. M. Landis, The Univ. of Texas at Austin (USA)

\section{SESSION 13 MAGNETIC SHAPE-MEMORY ALLOYS II}

6929 IR Dynamic strain-field hysteresis model for ferromagnetic shape memory Ni-Mn-Ga [6929-63]

N. N. Sarawate, M. J. Dapino, The Ohio State Univ. (USA) 
6929 iT Aluminum additions in polycrystalline iron-gallium (Galfenol) alloys [6929-66]

M. D. Brooks, E. Summers, R. Meloy, J. Mosley, Etrema Products, Inc. (USA)

6929 IU Elastic properties and auxetic behavior of Galfenol for a range of compositions [6929-67] H. M. Schurter, A. B. Flatau, Univ. of Maryland, College Park (USA)

6929 IV Miniature spherical motor using iron-gallium alloy (Galfenol) [6929-68]

T. Ueno, The Univ. of Tokyo (Japan); C. Saito, N. Imaizumi, Namiki Precision Jewel Co., Ltd. (Japan); T. Higuchi, The Univ. of Tokyo (Japan)

6929 IW Fully-coupled magnetoelastic model for Galfenol alloys incorporating eddy current losses and thermal relaxation [6929-69]

P. G. Evans, M. J. Dapino, The Ohio State Univ. (USA)

6929 1X Equivalence of magnetoelastic, elastic, and mechanical work energies with stressinduced anisotropy [6929-98]

C. Mudivarthi, S. Datta, Univ. of Maryland, College Park (USA); J. Atulasimha, North Carolina State Univ. (USA); A. B. Flatau, Univ. of Maryland, College Park (USA); P. G. Evans, M. J. Dapino, The Ohio State Univ. (USA)

\section{SESSION 15 MAGNETOSTRICTIVE MATERIALS II}

$69291 \mathrm{Y} \quad$ Performance improvements in Galfenol laminated rods with stress annealing [6929-70] J.-H. Yoo, Univ. of Maryland, College Park (USA); J. Restorff, M. Wun-Fogle, Naval Surface Warfare Ctr. (USA); A. Flatau, Univ. of Maryland, College Park (USA)

692912 Magnetomechanical coupling factor and energy density of single crystal iron-gallium alloys (Best Student Paper Award) [6929-71]

S. Datta, A. B. Flatau, Univ. of Maryland, College Park (USA)

692920 Modeling and computational analysis of materials exhibiting intrinsic magnetomechanical coupling [6929-72]

B. Kiefer, D. Rosato, C. Miehe, Univ. Stuttgart (Germany)

692921 Translatory and wobbling micro magnetostrictive actuator [6929-73]

T. Ueno, The Univ. of Tokyo (Japan); C. Saito, N. Imaizumi, Namiki Precision Jewel Co., Ltd. (Japan); T. Higuchi, The Univ. of Tokyo (Japan)

692922 Fully-coupled model for the direct and inverse effects in cubic magnetostrictive materials [6929-74]

P. G. Evans, M. J. Dapino, The Ohio State Univ. (USA)

692924 Predicting relationship between magnetostriction and applied field of magnetostrictive composites [6929-76]

X. Guan, X. Dong, Harbin Institute of Technology (China); J. Ou, Harbin Institute of Technology (China) and Dalian Univ. of Technology (China) 
692926 Development of a meso-scale thermo-magneto-mechanical free energy model for NiMnGa [6929-59]

P. Morrison, S. Seelecke, North Carolina State Univ. (USA); B. Krevet, M. Kohl,

Forschungszentrum Karlsruhe (Germany)

692927 Effects of electric field and poling on the response of multilayer piezoelectric film actuators with partial electrodes [6929-77]

Y. Shindo, F. Narita, M. Hirama, Tohoku Univ. (Japan)

692929 Characterisation of piezoelectric materials at high stress levels using electrical impedance analysis [6929-79]

A. Bowles, J. Gore, QinetiQ Ltd. (United Kingdom)

6929 2A Poly (ethylene oxide) - poly (ethylene glycol) blended cellulose electroactive paper actuator [6929-80]

S. K. Mahadeva, J. Nayak, J. Kim, Inha Univ. (South Korea)

6929 2C Characterization of the actuator behavior of blended-system ferrogels [6929-82]

G. Park, E. J. McLaurin, L. E. Faidley, lowa State Univ. (USA)

6929 2D Coupled electromechanical behavior of an interface electrode in a piezoelectric layer [6929-83]

B.-L. Wang, Y.-W. Mai, The Univ. of Sydney (Australia)

6929 2G Fabrication and electromagnetic characteristics of microwave absorbers containing carbon nanofibers and magnetic metals [6929-87]

K.-Y. Park, J.-H. Han, Korea Advanced Institute of Science and Technology (South Korea);

S.-B. Lee, J.-B. Kim, J.-W. Yi, S.-K. Lee, Korea Institute of Materials Science (South Korea)

6929 2L Structural dielectrics for multifunctional capacitors [6929-99]

D. M. Baechle, D. J. O'Brien, E. D. Wetzel, Army Research Lab. (USA)

6929 2M Carbon nanotube epoxy modified CFRPs: toward improved mechanical and sensing for multifunctional aerostructures [6929-100]

V. Kostopoulos, A. Vavouliotis, P. Karapappas, Univ. of Patras (Greece)

$69292 \mathrm{~N} \quad$ Electrospinning of continuous piezoelectric yarns for composite application [6929-101]

N. C. Lagoudas, Z. Ounaies, Texas A\&M Univ. (USA)

Author Index 


\title{
Symposium Committee
}

\author{
Symposium Chairs
}

Alison B. Flatau, University of Maryland, College Park (USA)

George Y. Baaklini, NASA Glenn Research Center (USA)

Donald J. Leo, Virginia Polytechnic Institute and State University (USA)

Kara J. Peters, North Carolina State University (USA)

Executive Committee

Alison B. Flatau, University of Maryland, College Park (USA)

George Y. Baaklini, NASA Glenn Research Center (USA)

Donald J. Leo, Virginia Polytechnic Institute and State University (USA)

Kara J. Peters, North Carolina State University (USA)

Mehdi Ahmadian, Virginia Polytechnic Institute and State University (USA)

Yoseph Bar-Cohen, Jet Propulsion Laboratory (USA)

Emilio P. Calius, Industrial Research Ltd. (New Zealand)

Marcelo J. Dapino, The Ohio State University (USA)

L. Porter Davis, Honeywell, Inc. (USA)

Michael A. Demetriou, Worcester Polytechnic Institute (USA)

Aaron A. Diaz, Pacific Northwest National Laboratory (USA)

Wolfgang Ecke, IPHT Jena (Germany)

Mehrdad N. Ghasemi-Nejhad, University of Hawai'i at Manoa (USA)

Victor Giurgiutiu, University of South Carolina (USA)

B. Kyle Henderson, Air Force Research Laboratory (USA)

Kumar V. Jata, Air Force Research Laboratory (USA)

Tribikram Kundu, The University of Arizona (USA)

Douglas K. Lindner, Virginia Polytechnic Institute and State University (USA)

Ajit K. Mal, University of California, Los Angeles (USA)

M. Brett McMickell, Honeywell, Inc. (USA)

Norbert G. Meyendorf, Fraunhofer-Institut für Zerstörungsfreie

Prüfverfahren (Germany) and University of Dayton (USA)

Zoubeida Ounaies, Texas A\&M University (USA)

Andrei M. Shkel, University of California, Irvine (USA)

Peter J. Shull, The Pennsylvania State University (USA)

Masayoshi Tomizuka, University of California, Berkeley (USA)

Vijay K. Varadan, University of Arkansas (USA)

Dietmar W. Vogel, Fraunhofer-Institut für Zuverlässigkeit und Mikrointegration (Germany)

H. Felix Wu, National Institute of Standards and Technology (USA)

Chung-Bang Yun, Korea Advanced Institute of Science and Technology

(South Korea) 
Downloaded From: https://www.spiedigitallibrary.org/conference-proceedings-of-spie on 26 Apr 2023

Terms of Use: https://www.spiedigitallibrary.org/terms-of-use 


\title{
Conference Committee
}

\author{
Conference Chair
}

Marcelo J. Dapino, The Ohio State University (USA)

Conference Cochair

Zoubeida Ounaies, Texas A\&M University (USA)

Program Committee

Hilary Bart-Smith, University of Virginia (USA)

Abhijit Bhattacharyya, University of Arkansas/Little Rock (USA)

L. Catherine Brinson, Northwestern University (USA)

Gregory P. Carman, University of California/Los Angeles (USA)

Constantin Ciocanel, University of Toledo (USA) and Northern Arizona University (USA)

Christopher P. Henry, HRL Laboratories, LLC (USA)

Marc Kamlah, Forschungszentrum Karlsruhe GmbH (Germany)

Ibrahim Karaman, Texas A\&M University (USA)

Dimitris C. Lagoudas, Texas A\&M University (USA)

Chad M. Landis, The University of Texas at Austin (USA)

Donald J. Leo, Virginia Polytechnic Institute and State University (USA)

JiangYu Li, University of Washington (USA)

Christopher S. Lynch, Georgia Institute of Technology (USA)

Karla M. Mossi, Virginia Commonwealth University (USA)

Robert C. O'Handley, Massachusetts Institute of Technology (USA)

Etienne Patoor, École Nationale Supérieure d'Arts et Métiers (France)

Ralph C. Smith, North Carolina State University (USA)

\section{Session Chairs}

1 Ferroelectrics I

Christopher S. Lynch, Georgia Institute of Technology (USA)

Karla M. Mossi, Virginia Commonwealth University (USA)

2 Ferroelectric Materials: Characterization

Gregory P. Carman, University of California/Los Angeles (USA)

JiangYu Li, University of Washington (USA) 
3 Ferroelectric Materials: Modeling

Marc Kamlah, Forschungszentrum Karlsruhe GmbH (Germany)

William S. Oates, Florida State University (USA)

4 Ferroelectrics II

Chad M. Landis, The University of Texas at Austin (USA)

Minoru Taya, University of Washington (USA)

5 Active Polymers

Karla M. Mossi, Virginia Commonwealth University (USA)

Kam W. Leong, Duke University (USA)

6 Active Composites I

Lisa M. Weiland, University of Pittsburgh (USA)

Vishnu B. Sundaresan, Virginia Polytechnic Institute and State University (USA)

$7 \quad$ Active Composites II

Jonghwan Suhr, University of Nevada/Reno (USA)

Zoubeida Ounaies, Texas A\&M University (USA)

8 Future of SMA I

Frederick T. Calkins, The Boeing Company (USA)

James H. Mabe, The Boeing Company (USA)

9 Future of SMA II

Ibrahim Karaman, Texas A\&M University (USA)

Constantin Ciocanel, University of Toledo (USA) and Northern Arizona University (USA)

10 Shape-Memory Materials I

Christopher P. Henry, HRL Laboratories, LLC (USA)

Marcelo J. Dapino, The Ohio State University (USA)

11 Shape-Memory Materials II

Ralph C. Smith, North Carolina State University (USA)

John A. Shaw, University of Michigan (USA)

12 Magnetic Shape-Memory Alloys I

Stefan S. Seelecke, North Carolina State University (USA)

Robert C. O'Handley, Massachusetts Institute of Technology (USA)

13 Magnetic Shape-Memory Alloys II

Dimitris C. Lagoudas, Texas A\&M University (USA)

Neelesh N. Sarawate, The Ohio State University (USA) 
14 Magnetostrictive Materials I

Bjoern Kiefer, University Stuttgart (Germany)

Eric M. Summers, ETREMA Products, Inc. (USA)

15 Magnetostrictive Materials II

Phillip G. Evans, The Ohio State University (USA) 
Downloaded From: https://www.spiedigitallibrary.org/conference-proceedings-of-spie on 26 Apr 2023

Terms of Use: https://www.spiedigitallibrary.org/terms-of-use 